\title{
FINANCIAL REPORT
}

Board of Directors

African Studies Association, Inc.

Los Angeles, Californta

We have examined the balance sheet of African Studies Association, Inc. as of December 31,1987 , and the related statements of activity, changes in fund balance, and changes in financial position for the year then ended. Our examination was made in accordance with generaliy accepted auditing standards, and accordingly, included such tests of the accounting records and such other auditing procedures as we considered necessary in the c1rcumstances, except as stated in the following paragraph.

Because we were not engaged as auditors until after December 31, 1986, we were not present to observe the physical inventory taken at that date and we have not satisfied ourselves by means of other procedures concerning inventory quantities. The amount of the inventory at December 31, 1986, enters materially into the determination of the results of operations and changes in financial position for the year ended December 31, 1987. Therefore, we do not express an opinion on the accompanying statements of activity, changes in fund balance, and changes in financial position for the year ended December 31, 1987.

In our opinion, the accompanying balance sheet presents fairly the financial position of African Studies Association, Inc. at December 31, 1987, in conformity with generaIly accepted accounting principles applied on a basis consistent with that of the preceding year.

WIDEMAN, FETMAN, LEVY, SAPIN \& KO An Accountancy Corporation

By

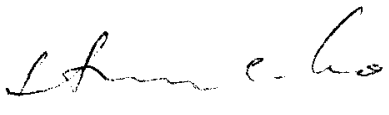

March 1, 1988 
African Studies Association, Inc.

Bal ance Sheet

December 31, 1987

\section{Assets}

Current Assets

Cash

Inventories (Note 2)

36,498

31.533

Total Current Assets

68,031

Fixed Assets (Note 3)

Office equipment

30,362

Less: Accumulated depreclation

24,604

Total Fixed Assets

5.758

Total Assets

73.789

Liabilities and Fund Balance

Current Liabilities

Membership dues received in advance

28,931

Due to University of California

11,503

Total Current Liabilities

40,434

Fund Balance

33,355

Total Liabilities and Fund Balance

73,789

The accompanying notes are an integral part of these statements. 
African Studies Association, Ine.

Statement of Activity

Year Ended December 31, 1987

\section{Revenue}

Membership dues

88,234

Sale of publications

37,615

Annual meeting gross receipts

69,359

Rental of mailing list

4,273

Interest

1,096

Grant fund recelved (Note 5)

57,170

Total Revenue

257,747

Expenses

Publications

62,618

Annual meetings

42,400

Board meetings

10,783

Awards

500

General and administrative

118,861

Grant fund expensed (Note 5)

3,543

Total Expenses

270,705

Excess of Expenses Over Revenue

$(12,958)$

The accompanying notes are an integral part of these statements. 
African Studies Association, Inc.

Statement of Changes in Fund Balance

Year Ended December 31,1987

\begin{tabular}{|c|c|c|c|}
\hline & $\begin{array}{l}\text { Grant } \\
\text { Fund }\end{array}$ & $\begin{array}{l}\text { Unrestricted } \\
\text { Fund } \\
\end{array}$ & Total \\
\hline Fund Balance at January $1,1987$. & 7,348 & 46,313 & 53,661 \\
\hline Excess (defictency) for the year & 21,627 & $(34,585)$ & $(12,958)$ \\
\hline $\begin{array}{l}\text { Unused } 1986 \text { grant fund returned to } \\
\text { Ford Foundation }\end{array}$ & $(7,348)$ & 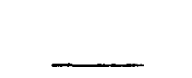 & $(7,348)$ \\
\hline Fund Balance at December 31,1987 & 21,627 & 11,728 & 33,355 \\
\hline
\end{tabular}

The accompany ing notes are an integral part of these statements. 
African Studies Assoctation, Inc.

Statement of Changes in Financial Position

Year Ended December 31,1987

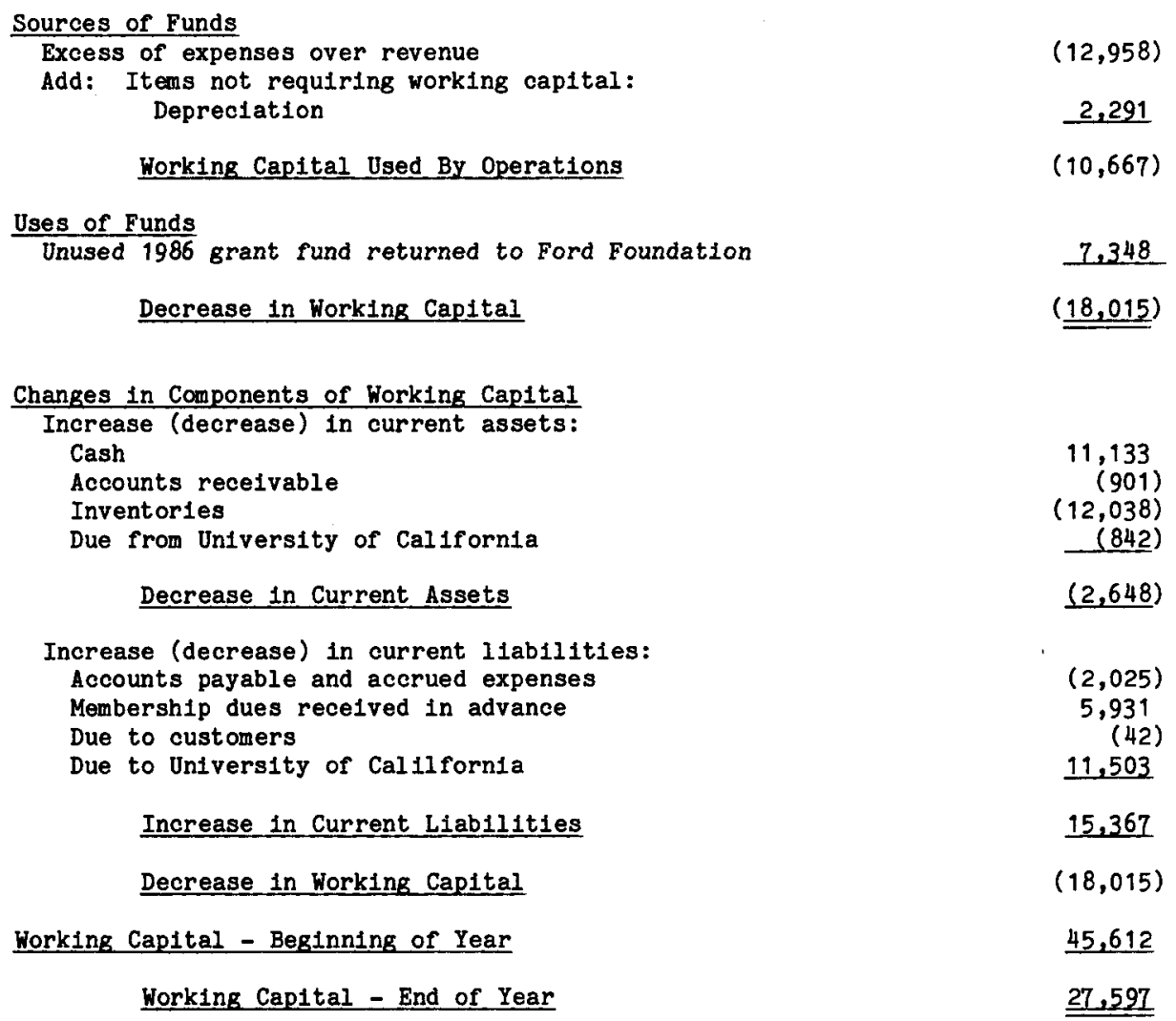

The accompanying notes are an integral part of these statements. 
African Studies Association, Inc.

Notes to Financial Statements

December 31,1987

NOTE 1 Operations and Tax Status

The African Studies Assoc1ation, Inc. was organized in 1957 as a non-profit membership corporation to bring together persons with a scholarly and professional interest in Africa, to provide useful services to the Africanist community, and to publish and distribute appropriate scholarly and informational materials. Membership is open to institutions and individuals. The Association is exempt from Federal income taxes under Section 501 (c) (3) of the Internal Revenue Code.

NOTE 2 Inventories

Inventories of books are stated at the lower of cost or market. Cost is determined using the first-in, first-out method. Estimated costs were used in valuing inventories for which cost information is not available.

NOTE 3 Fixed Assets

Fixed assets are stated at cost. Depreciation has been provided by the use of the straight line method over the estimated useful lives of the assets.

NOTE 4 Agreements

The Association and Emory University agreed that the Association be located on the campus of Emory University for a period of five years from January 1, 1988 to December 31, 1992. The agreement provides that Emory University will pay for certain moving, operating and renovation expenses up to specified amounts in connection with the moving of the Secretariat of the Association.

NOTE 5 Grant Funds

The Association received a grant from the Ford Foundation in the amount of $\$ 50,000$. The fund is to be used for forelgn participants in the Association's 1987 and 1988 annual meetings in the amount of $\$ 30,000$ and $\$ 20,000$, respectively.

During 1987 , the Association has been awarded a grant from the National Endowment for the Humanities in the amount of $\$ 19,208$. The fund is restricted to the publication of a book listing all American and Canadian doctoral dissertations (from 1975 to 1987) about Afr1ca. 